\title{
The Hell-Bound Bandwagon: Train Rooftop Riding in Lagos Metropolis, Nigeria
}

\author{
Olorunfemi Ayodeji Olojede ${ }^{1}$
}

Received: 10 August 2018/Revised: 6 December 2018/Accepted: 14 December 2018/Published online: 17 January 2019

(C) The Author(s) 2019

\begin{abstract}
Media reports on train mishaps and havocs emanating from rooftop riding abound; however, there has been very limited effort on the empirical investigation of why daredevils embark on this utter suicide mission. Besides, studies that rigorously examined profiles of the perpetrators of the dastardly act are hard to come by in the literature of railway transport. Against this background, this study examined the menace of train rooftop riding in Lagos Metropolis, Nigeria, with a view to evolving a policy response that could curtail the life-threatening nuisance. Towards achieving this aim, specific objectives were formulated. These were to examine the socioeconomic characteristics of train rooftop riders in Lagos Metropolis, determine the motivations for train rooftop riding in the study area, assess the efforts made by the authorities to discourage train rooftop riding in the study area, and proffer policy recommendations towards engendering a safe rail transport milieu. Data were obtained through participant observation, interview and questionnaire administration. The respondents comprised 64 conveniently sampled rooftop riders, 183 law-abiding passengers of three Diesel Multiple Units and three Mass Transit Trains selected using multistage sampling, and the 113 staff members of the Nigerian Railway Corporation consisting of 20 engineers, 79 conductors and 14 ticket vendors. The study found that train rooftop riding had defied all the measures taken against it in the study area. It
\end{abstract}

Olorunfemi Ayodeji Olojede

olorunfemiolojede@gmail.com; olojede.ayodeji@mut.ac.za

1 Human Settlement Unit, Mangosuthu University of Technology, Umlazi, Durban, South Africa

Communicated by Xuesong Zhou. characterized most trips but was prevalent at the morning and evening peak periods ( $35.2 \%$ and $59.2 \%$, respectively). All the rooftop riders were middle-aged men. None of them admitted to ever falling off before; however, 28 (43.8\%) admitted to being scared of falling off, while 40 (62.5\%) boasted they could not possibly fall off. Two categories of motivations for rooftop riding were found: 'perceived' and 'real'. Smoking (47.0\%), substance abuse (23.0\%) and criminal tendencies $(19.7 \%)$ were among the perceived motivations, while space inadequacy $(37.5 \%)$, queue avoidance $(50.0 \%)$ and adventure $(34.4 \%)$ were among the real motivations. Given an overall improvement in the railway services, $28(43.8 \%)$ would stop, $18(28.1 \%)$ would not stop, and $18(28.1 \%)$ were unsure they would stop rooftop riding. The study concluded that the menace of train rooftop riding was undesirable. Consequently, practical policy recommendations were proffered towards curbing the menace.

Keywords Rooftop riding · Nigerian Railway Corporation - Operations - Mass Transit Train - Diesel Multiple Units · Lagos Metropolis

\section{Introduction}

One appealing feature of rail transport is its comparatively high degree of safety. According to the International Railway Safety Council [1], railways provide a safe and sustainable form of transport that is typically safer than all other transport modes with the exception of commercial aviation. Likewise, in his review of the statistics and economics of railway safety in Great Britain, the European Union and the USA, together with some results for Finland and Japan, Evans [2] found that railway safety has even 
improved over recent decades as fatal train collisions and derailments have become infrequent and account for only a small minority of railway fatalities. However, happenings from different parts of the world have been eroding this important affection, especially as brought about by train rooftop riding.

From Africa to Asia, and from Europe to North America, there are staggering statistics from many countries on self-induced fatalities from the rail system brought about by this practice. Train rooftop riding, which has been taking place since 1947 in Bangladesh, India and Pakistan, is one of the leading causes of death among children. The menace of kids hanging out on the tracks and rooftop riding is more rampant than that of American kids riding in the back of pickup trucks [3]. Even among adults, the trend is worrisome [4]. Thus, it is arguable that, generally, people of varied socio-economic backgrounds join the bandwagon of train rooftop riding.

Media reports from Nigeria [5], UK [6], Russia and France [7], India [8], Indonesia [9, 10], Bangladesh [3] and other countries affirm the ugly trend in train rooftop riding. For instance, a head teacher in the UK was caught on camera train surfing with a group of youths thought to be his pupils [6]. Again, in Mumbai, India, for days in 2016 the railway police tried to identify a man who climbed onto the roof of a local train to show off stunts, as recorded by a passenger on another train [8]. In Bangladesh, a bicycle motocross rider threw tricks off by riding on the rooftop of a moving train, 'putting James Bond to shame' [3]. Unabated, daredevil rooftop riders continue with this suicidal act apparently for the fun of it.

Meanwhile, the reprehensible act of train rooftop riding has not been without its well-reported attendant risks of injuries and fatalities [7, 10-12]. In 2001, a 21-year-old student from Indonesia fell off the roof of a train and was struck by another [10]. In the course of a week in Mumbai, there were 74 incidents as a result of train rooftop riding [13]. In 2013, a young man reportedly riding the roof of a Paris Metro was killed when the train entered a tunnel. Earlier in 2011, a similar incident happened in Paris, France, with two students' lives ending in a gruesome death when surfing the Moscow Metro [7]. Also in 2011, at least 14 young job seekers riding on the roof of an overcrowded train were killed, while nine others became bedridden after it hit a low overhead bridge in northern India [11]. In addition, in 2008, a record of 17 people died every weekday on Mumbai's suburban railway network [12]. Moreover, in Nigeria, scores of passengers plunged to death in 2015 when Mass Transit Trains (MTTs) collided with a truck at the Agege level crossing [14].

With a view to putting an end to the self-inflicted calamity of train rooftop riding, concerned authorities have employed various measures and approaches including spraying dyed water or oil, the use of barbed wire, dogs, public enlightenment even through cleric intervention, performances of crowd-pulling music stars, arrest and prosecution, as well as the suspension of heavy concrete balls at strategic points over rail tracks [9, 15-20]. Of all these measures, however, it seems that only the bizarre solution of installing steel support with hanging concrete balls over rail tracks, which was embarked upon in Indonesia, has proved absolutely efficacious. According to Quiano [9] and Tan [20], none of the earlier methods tried in keeping riders off the train top had yielded significant success prior to the installation of the concrete balls.

In Nigeria, the menace of train rooftop riding has defied all measures. However, only arrest and prosecution have been the most common measures. It was reported in 2015 that the Nigeria Police Force, Railway Command in Lagos State, arrested 58 out of about 200 sighted suspected hoodlums in just one evening around $8 \mathrm{pm}$ for riding on the rooftop of moving trains $[18,19]$. Again, 105 rooftop riders were arrested in November 2016 out of which 36 were arraigned in court [21]. Many times, the rooftop riders resist arrest and even fight back. For instance, Aderibigbe [22] reported that in an attempt to resist arrest in the Agege area of Lagos in November 2016, rooftop riders unleashed mayhem as the train approached, throwing stones and other objects at the police officers. In the process, a baby strapped to her mother's back was hit on the head and died the following morning. Irate Agege youths stormed the station, destroying properties of NRC and demanding a stop of train services until rooftop riding was eradicated. Several passengers were injured in the mayhem. The corporation had to foot the medical bills and temporarily suspend its services. There are many other scary reports.

From the foregoing, it is evident that media reports on train mishaps and havocs emanating from rooftop riding abound. However, there has been very limited effort on the empirical investigation of why daredevils embark on this utter suicide mission. Besides, studies that rigorously examined profiles of the perpetrators of the dastardly act are hard to come by in the literature of railway transport. Against this background, this study set out to explore the menace of train rooftop in Lagos Metropolis in Nigeria with a view to evolving a policy response that could curtail the life-threatening nuisance. Towards achieving this aim, specific objectives were formulated. These were to examine the socio-economic characteristics of train rooftop riders in Lagos Metropolis, determine the motivations for train rooftop riding in the study area, assess the efforts made by the authorities to discourage train rooftop riding in the study area and proffer policy recommendations towards engendering a safe rail transport milieu. 
Fig. 1 Map of Nigeria indicating Lagos State. Source: National Space Research and Development Agency (2018)
Fig. 2 Map of Lagos State indicating Lagos Metropolis. Source: National Space Research and Development Agency (2018)
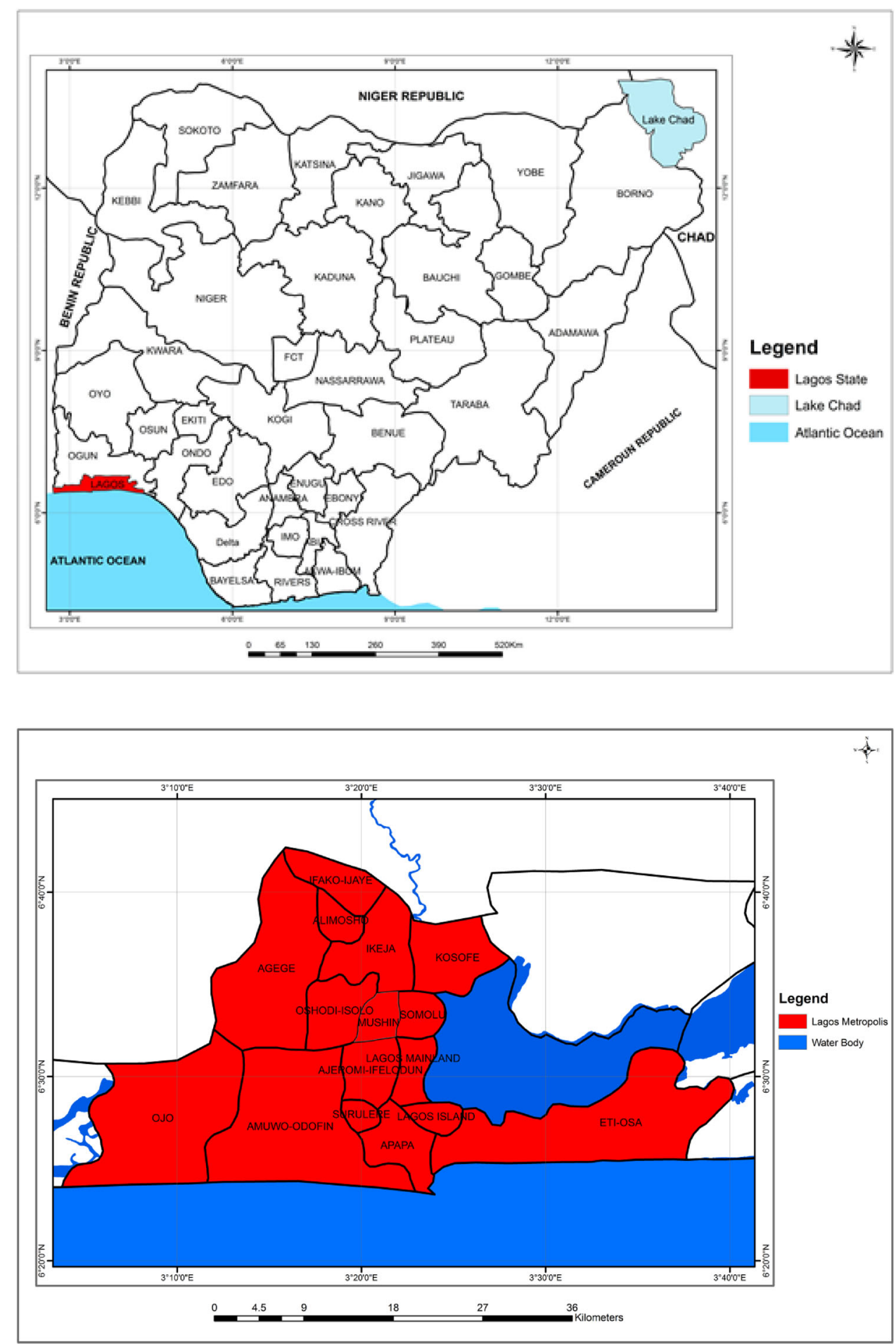

\section{The Spatial Context of the Study}

Lagos was the capital of Nigeria until 1992 when the federal capital was moved to Abuja. Located in south-west Nigeria, it lies between latitude $6^{\circ} 22^{\prime}$ and $6^{\circ} 52^{\prime}$ north of the equator with a longitudinal stretch of $2^{\circ} 42^{\prime}$ and $3^{\circ} 42^{\prime}$ east of the Greenwich Meridian (Fig. 1). The state occupies an area of 3577 square kilometres, which is $0.4 \%$ of the nation's territorial landmass. It is the smallest state in Nigeria in terms of land area [23] but also the most economically buoyant in the country. As shown in Fig. 2, Lagos State is made up of 20 local government areas. However, the term Lagos Metropolis, which accounts for about $80 \%$ of the population of the entire state [24], is used 
to refer to 16 of the 20 local government areas with the exclusion of Badagry, Ikorodu, Epe and Ibeju-Lekki local government areas. With an estimated population of $14,842,000$ people, Lagos State is the most densely populated state in Nigeria [25].

As a rule, Lagos State is considered the economic and commercial capital of Nigeria. Generally, traffic in the state is characterized by heavy congestion, pollution, accident and several other negatives. Meanwhile, as of today, Lagos is one of the very few Nigerian states in which all the modes of transport available in the country-air, water, road and rail—are found. Both interstate travel rail services and intercity shuttle services are available in the state. The intercity shuttle services run from the Iddo terminus in Lagos State to Ijoko/Kajawla (Kajola) in Ogun State, while the interstate, long-distance travel rail services link up the state with other parts of the country. Rail services in Nigeria are solely regulated and operated by the Nigerian Railway Corporation (NRC), which was established in 1955. However, the Lagos railway had started under the management of the British colonial government in March 1896 when the construction of Lagos-Ibadan railway was initiated. Later in 1898, the colonial government linked Lagos Island with the Mainland. In the same year, the railway was extended to the contiguous Ogun State.

The Lagos Shuttle Services started operation in 1902 with the Lagos Steam Tramway which was used to convey passengers and goods from Iddo to Custom Wharf and Ereko Market. The tramway was operated by the Lagos Government Railway. However, the operation ended in 1913 owing to the renewal of original rolling stock. The Lagos Intercity Shuttle Services (corridor from Iddo to Ijoko/Kajawla) started operation in 2001 through an initiative called Lagos Metropolitan Mass Transit Train Service with its terminus at Iddo and covering about 26 kilometres [26, 27]. At the beginning of its operation, a Mass Transit Train (MTT) was used to convey passengers in a rural-urban directional movement. Later on, more MTTs were added. The Diesel Multiple Unit (DMU) trains were later introduced in 2001 to revitalize the railway system [28]. The rail line falls within the Lagos Megacity region.

According to the information provided by NRC, the rail system between Iddo and Ijoko/Kajawla comprises 25 train stations. These stations are all stopping points for the transit service and are principally used for the loading and unloading of goods and passengers. Some of these stations have multiple-track facilities for coach attachment and detachment. The MTT is generally considered as the economy train because of its cheaper fare charges, the

\footnotetext{
1 As of 27th July 2018, a US dollar (US\$1) exchanged for Nigerian 364.11 naira (N364.11).
}

number of coaches hauled and the seating capacity. The DMU, on the other hand, is considered as a first-class train because of the air-conditioned coaches, small number of coaches hauled and reduced seating capacity which make it more expensive. The rail service operates from Monday through Saturday and runs three shifts: morning (06:00-14:00), afternoon (14:00-22:00) and night (22:00-06:00) shifts. As at the time of this survey, the fare charged per trip either way regardless of the boarding station was 230 naira $^{1}$ for Mass Transit Train (MTT) and 300 naira for Diesel Multiple Unit (DMU) train during off peak period. However, the fare charged by the DMU during the peak period (06:00-12:59 and 16:01-21:00) could go up to as high as 750 naira.

\section{Research Methodology}

A combination of three survey instruments was employed in obtaining the data for the study. These were participant observation, structured interview (of the Head of Operations, who was purposively sampled) and two sets of questionnaire. Participant observation was deemed relevant for this study as it was important for deeper understanding of the phenomenon under investigation. It also guided the research in improvising some unpremeditated questions, especially when the rooftop riders and the operations staff were being interviewed. In a way, it also served as a control for the data gathered in the course of the survey as it allowed access to the context and meaning surrounding what the respondents and interviewees said and did [29]. The first set of questionnaire was administered on 64 conveniently sampled rooftop riders who were willing to participate in the study. This number was considered sufficient considering the nature of the research. A lot of efforts, caution and diplomacy had to be employed as many of the rooftop riders were unapproachable, cantankerous and violent. Meanwhile, as much as possible, representativeness was taken into consideration. The second set of questionnaire was administered on 183 law-abiding passengers, who were selected through multistage sampling, as well as all the 113 operations staff of the Nigerian Railway Corporation, comprising 20 engineers, 79 conductors and 14 ticket vendors.

Preliminary investigation revealed that an average of ten trains took off from the Iddo terminus every day. These comprised three Diesel Multiple Units (DMUs) and seven Mass Transit Trains (MTTs). Each DMU had three coaches, while each MTT had ten coaches with 72 and 90 coach seating capacities, respectively. Two, two and three of the seven MTTs, and each of the three DMU trains were scheduled for operation in the morning, afternoon and evening hours of service, respectively. Three MTTs were 
randomly selected, one for each hour of service, while all the three DMUs were selected for the three hours of service-one for each service hour. Thus, for each hour of service, one MTT and one DMU were covered by the survey. In each train, $50 \%$ of the coaches were randomly sampled: five MTTs and two DMUs. In each coach, $10 \%$ of the passengers were randomly selected for survey: nine in each MTT coach and eight in each DMU coach. As such, 45 passengers were selected from each MTT coach, while 16 passengers were selected from each DMU. In all, a total of 135 passengers were selected from the MTT, while a total of 48 passengers were selected from the DMU. Eventually, a grand total of 183 law-abiding passengers, who were not involved in rooftop riding, were surveyed in this study. Simple descriptive statistical tools were employed in the analysis of the data collected. The tools were mainly frequency distribution and percentages. In addition, content analysis was used to analyse the responses to interview questions and the open-ended questions in the questionnaires.

Pictures of cross sections of rooftop riders were taken to supplement the data obtained. However, this was very discreetly done as the rooftop riders were notorious for their uncanny aggressiveness. There have been reports of their beating up journalists and passers-by who dared take snapshots of their activities. They claim that people who take their photographs 'disrespect and ridicule' them by posting those pictures on social media. At the time of this survey, some of the research assistants were actually pelted with stones and other dangerous objects. To some extent, this challenge adversely affected the quality of the snapshots taken of the rooftop riders. Another challenge faced in the course of the survey was that none of the beggars on the train was willing and/or intellectually capable enough to participate in the study. Six of them were supposed to be sampled but had to be skipped. Thus, it was difficult to profile them analytically.

\section{Results and Discussion}

\subsection{Socio-economic Characteristics of Operations Staff}

The operations staff comprised 20 engineers, 79 conductors and 14 ticket vendors. All the 20 engineers were male with ages ranging from 37 to 63 years. Eleven $(55.0 \%)$ of them had senior or technical education, while the remaining 9 $(45.0 \%)$ had tertiary education. The lengths of their work experience ranged from 10 to 35 years with 20 years (for 5 or $25 \%$ of them) as the modal length of work experience at NRC. Their monthly incomes were in two categories: 46,200 naira earned by $8(40 \%)$ and 50,000 naira earned by
$12(60 \%)$ of the engineers. Seventy-four $(93.7 \%)$ of the 79 conductors were male, while $5(6.3 \%)$ were female. Their ages ranged from 28 to 45 with a mean and standard deviation of 35 and 4.9 , respectively. Sixty (75.9\%) of the conductors had senior secondary or technical education, while $19(24.1 \%)$ had tertiary education. The minimum average monthly income, earned by 39 (49.4\%), was 40,000 , while the maximum was 50,000 naira, earned by $18(22.8 \%)$. The mean length of work experience at NRC was approximately nine years, while the modal length of work experience was seven years. Whereas $6(42.9 \%)$ of the ticket vendors were male, $8(57.1 \%)$ were female. Their ages ranged from 27 to 41 years with a mean value of 32 years. Four $(28.6 \%)$ of the vendors had senior secondary or technical education, while $10(71.4 \%)$ had a tertiary education. Both the mean and modal lengths of work experience of the vendors at NRC were seven years.

\subsection{Socio-economic Characteristics of Law-Abiding Passengers}

A quick survey of the socio-economic characteristics of the law-abiding passengers reveals that 105 (57.4\%) were male, while $78(42.6 \%)$ were female. Three (1.6\%) were under $18,33(18.0 \%)$ were in the $18 \sim 30$ age bracket, 139 $(76.0 \%)$ were in the $31 \sim 60$ age bracket, while $8(4.4 \%)$ were over 60 years of age. The income distribution of the law-abiding passengers shows that $19(11.0 \%)$ earned at most 20,000 naira monthly, $84(48.8 \%)$ were in the $20,001 \sim 70,000$ naira income group, while $69(40.2 \%)$ earned over 70,000 per month. Thirty-one (16.9\%), 144 $(78.7 \%)$ and $8(4.3 \%)$ were single, married and divorced/ widowed, respectively. Six $(3.3 \%)$ of the passengers had no formal education, $5(2.7 \%)$ had a primary/adult education, $7(3.8 \%)$ had a junior secondary education, $50(27.3 \%)$ had a senior secondary or technical education, while 115 $(62.8 \%)$ had a post-secondary education in a college of education, polytechnic or university. Further, 17 (9.3\%), 52 (28.4\%), 89 (48.6\%), $2(1.1 \%)$ and $23(12.6 \%)$ of the passengers were students, civil servants, private sector workers, retirees and traders, respectively. Fifty-two (28.4\%) of the passengers claimed they had personal vehicles, while $131(71.6 \%)$ reported they had no personal vehicle.
Table 1 Age distribution of rooftop riders

\begin{tabular}{llcr}
\hline S.no. & Age & Freq. & \multicolumn{1}{l}{$\%$} \\
\hline 1. & $21-30$ & 27 & 42.2 \\
2. & $31-40$ & 35 & 56.2 \\
3. & $41-50$ & 2 & 1.6 \\
Total & & 64 & 100.0 \\
\hline
\end{tabular}


Table 2 Marital status of the rooftop riders

\begin{tabular}{llcrr}
\hline S.no. & Marital status & Freq. & \multicolumn{1}{c}{$\%$} & Cum. \% \\
\hline 1. & Single & 25 & 39.1 & 39.1 \\
2. & Married & 35 & 54.7 & 93.8 \\
3. & Divorced/Widowed & 4 & 6.2 & 100.0 \\
Total & & 64 & 100.0 & \\
\hline
\end{tabular}

\subsection{Socio-economic Characteristics of Rooftop Riders}

All the 64 (100.0\%) rooftop riders seen and sampled were male. Their ages ranged from 23 to 47, the mean, median and standard deviation being approximately 32 years, 32 years and 5.04, respectively. The age distribution of the rooftop riders is presented in Table 1. As seen in the table, most (56.2\%) of the rooftop riders were between 31 and 40 years old. Just two of them were over 40 years. This implies that the train rooftop riders in Lagos were mainly middle-aged men.

From Table 2, where the marital status of the rooftop riders is presented, it is clear that more than half the number (35 or $54.7 \%$ ) of the riders were married. The percentage of these that were divorced or widowed was negligible $(6.2 \%)$. Among Nigerians, any married man is believed to be responsible in many ways. Thus, it could be deduced that the majority of the riders should be responsible enough, in the Nigerian society context, as not to be engaged in this kind of reckless act.

Table 3 gives the average monthly income distribution of the rooftop riders. As seen in the table, $42.2 \%$ of them earned less than 21,000 naira on a monthly basis. This amount is approximately the monthly naira equivalent of $\$ 1.9$ per day which is the World Bank's poverty line for the extremely poor [30]. Thus, it is obvious that approximately $42.2 \%$ of the rooftop riders were extremely poor, going by the World Bank's standard. This suggests that poverty might be a hidden factor influencing the tendency to ride on the roof of trains in the study area.

Table 3 Income distribution of the rooftop riders

\begin{tabular}{llrrr}
\hline S.no. & Income (naira) & Freq. & $\%$ & Cum. \% \\
\hline 1. & $<21,000$ & 27 & 42.2 & 42.2 \\
2. & $21,000-30,000$ & 21 & 32.8 & 75.0 \\
3. & $31,000-40,000$ & 11 & 17.2 & 92.2 \\
4. & $41,000-50,000$ & 5 & 7.8 & 100.0 \\
Total & & 64 & 100.0 & \\
\hline
\end{tabular}

Table 4 Educational qualifications of the rooftop riders

\begin{tabular}{llcrr}
\hline S.no. & Highest qualification & Freq. & \multicolumn{1}{c}{$\%$} & Cum. \% \\
\hline 1. & Primary/adult & 3 & 4.7 & 4.7 \\
2. & Junior secondary & 10 & 15.6 & 20.3 \\
3. & Senior secondary/technical & 48 & 75.0 & 95.3 \\
4. & Tertiary & 3 & 4.7 & 100.0 \\
Total & & 64 & 100.0 & \\
\hline
\end{tabular}

Education goes a long way in an individual's behaviour. The educational qualifications of the rooftop riders are summarized in Table 4. The table shows that none of the riders was a stark illiterate. Approximately $4.7 \%$ of the riders had a primary or adult education, $15.6 \%$ had a junior secondary education, $75.6 \%$ had senior secondary or technical education, while $4.7 \%$ claimed that had been to a post-secondary educational institution. A careful look at the table suggests that at least $79.7 \%$ of the rooftop riders had at least a senior secondary education. Thus, it is expected that they should be knowledgeable enough to know the risks involved in the act. This finding corroborates the earlier discussion on Table 2 about the sense of responsibility.

\subsection{Characteristics of and Motivations for Rooftop Riding in Lagos Metropolis}

According to the operations staff, rooftop riding was a daily activity which constituted one of the major challenges facing the operation of the Lagos Shuttle Services. It was found that it characterized most trips, but was more pronounced on MTT than DMU. This was attributable to the 'executive' nature of the DMU, the charge of which was more expensive and the design of which did not encourage rooftop riding. As computed from the responses of the operations staff, on the average, rooftop riding was prevalent at peak periods $(35.2 \%$ for morning trips and

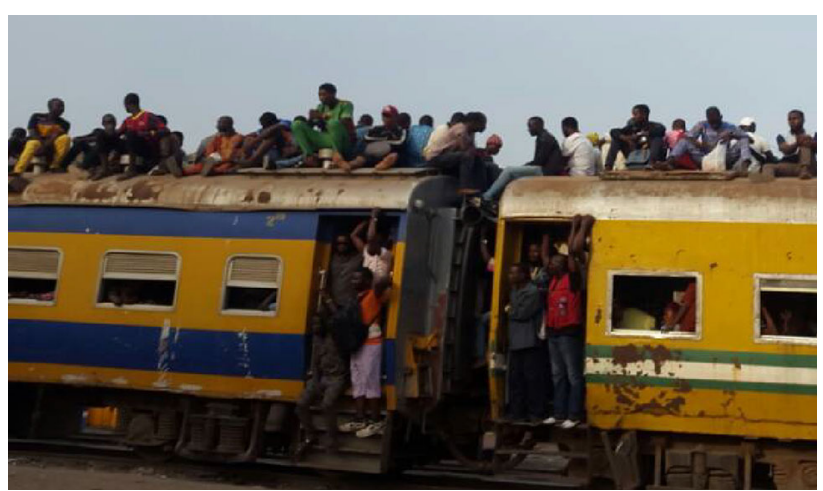

Fig. 3 Rooftop riders on a moving train 


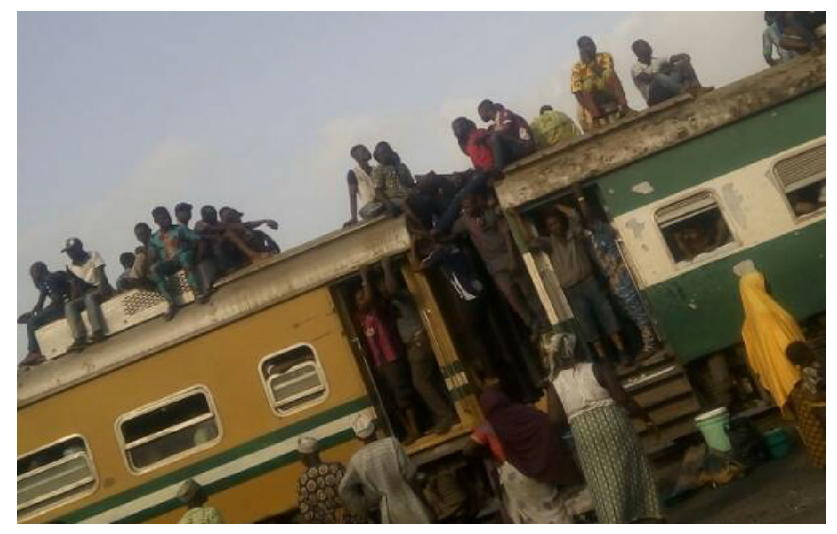

Fig. 4 Riders mounting a stationary train

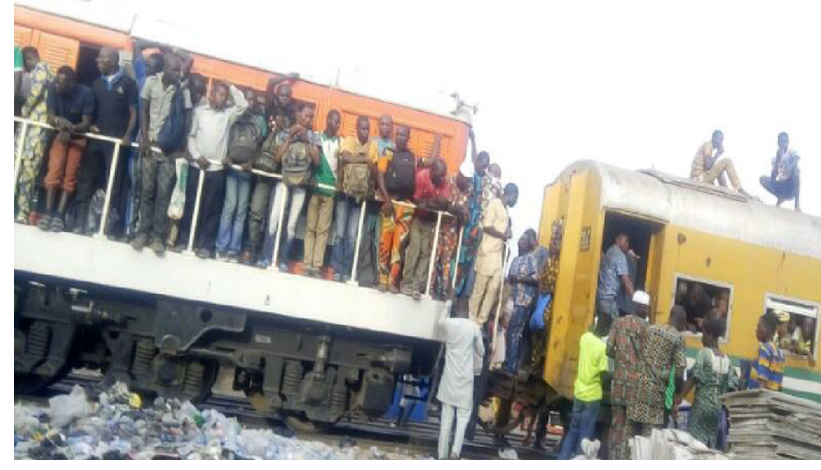

Fig. 5 Illegal occupation of the engine compartment

$59.2 \%$ for evening trip). The remaining $5.6 \%$ took place during afternoon trips. Rooftop riders made for the rooftops of the trains as soon as the trains approached the stations. Some of them also took to other 'available' spaces they could find, including the locomotive engine compartment, cargo and electricity generating set cabins (Figs. 3, 4, 5). Many of the rooftop riders could be so violent that it would be risky for anyone to attempt getting in their way. At times, they carried weapons with them and even threw objects at people who tried to take their pictures.

Thirty-four (53.1\%), $21(32.8 \%)$ and $9(14.1 \%)$ of the rooftop riders claimed they always, usually and seldom rode on the rooftop, respectively. In addition, 9 (14.1\%), 25 $(39.1 \%)$ and $30(46.9 \%)$ of them had been involved in the act for less than a year, between a year and two, and over two years, respectively. None $(0.0 \%)$ of them admitted to ever falling off before; however, $28(43.8 \%)$ admitted to being scared of falling off, while $40(62.5 \%)$ boasted they could not possibly fall off. Further, 23 (35.9\%), 35 (54.7\%) and $6(9.4 \%)$ of the rooftop riders admitted that rooftop riding was dangerous, could be dangerous and was not dangerous, respectively. Given overall improvement in the railway services, $28(43.8 \%), 18(28.1 \%)$ and another 18 (28.1\%) responded that they would stop, they would not stop, and they were unsure they would stop the act, respectively. Moreover, given improved fortune or financial breakthrough, 52 (81.3\%), 5 (7.8\%) and 7 (10.9\%) of the rooftop riders thought that they could stop, they could not stop, and they were unsure they could stop, respectively. All the rooftop riders considered the taking of their pictures and posting same on social media rude.

In Table 5, 12 of the strongest motivations for rooftop riding were analysed. The six strongest motivations identified by the law-abiding passengers are labelled 'perceived motivations', while the six strongest motivations identified by the rooftop riders were labelled 'real motivations'. This arbitrary classification of motivations is premised on the argument that law-abiding passengers can only express their opinions on rooftop riding from their own non-participatory perspective, while rooftop riders are believed to be in the best position to offer an explanation on why they opt for the daredevil act. Based on this arbitrary classification, low sense of responsibility (as perceived by $57.9 \%$ of the law-abiding passengers) and unwillingness to pay the fare (as perceived by $56.8 \%$ of the law-abiding passengers) were the two strongest motivators for train rooftop riding in Lagos Metropolis. Three other moderately strong perceived motivations were identified as smoking (of Indian hemp: 47.0\%), substance abuse (23.0\%) and criminal tendencies $(19.7 \%)$. Meanwhile, the smartness of the riders had the lowest rating in their opinion. This implies that, generally, the law-abiding passengers did not think that the rooftop riders engaged in the act to show off any skill but for ignoble reasons. This implies that the law-abiding passengers held the rooftop riders in low esteem.

In addition, Table 5 gives the motivations for rooftop riding in the opinion of the perpetrators of the act themselves. Beating the rush hours and the avoidance of queues were identified as the two strongest motivations with $59.4 \%$ and $50.0 \%$, respectively. With $37.5 \%$, space inadequacy was identified as the third strongest motivation. Participant observation afforded this research an understanding of this particular motivation. It was observed that as the trains moved from one station to another, they got filled up such that on arrival at some stations, there would be no space left for passengers who had valid tickets on them. A particular overflow passenger, who squeezed himself into one of the coaches at a particular station and did not climb the rooftop, claimed that an operations staff member actually asked him to climb the roof if he could not secure a space in any of the coaches. Generally, the claims of rooftop riders tended not to give them out as irresponsible riffraff as the law-abiding passengers saw them. However, the risks associated with the act would make the opinion of the law-abiding passengers seem plausible. 
Table 5 Motivations for rooftop riding

\begin{tabular}{lrrlll}
\hline Perceived motivations & Freq. & $\%$ & Real motivations & Freq. & $\%$ \\
\hline Irresponsibility & 106 & 57.9 & Beating the rush hours & 38 & 59.4 \\
Unwillingness to pay & 104 & 56.8 & Queue avoidance & 32 & 50.0 \\
Smoking & 86 & 47.0 & Space inadequacy & 24 & 37.5 \\
Substance abuse & 42 & 23.0 & Exorbitant fare & 23 & 35.9 \\
Criminal tendencies & 36 & 19.7 & Adventure/stunts show-off & 22 & 34.4 \\
Smartness/skilfulness & 10 & 5.5 & Fresh air inadequacy & 14 & 21.9 \\
No. of respondents & 183 & & No. of respondents & 64 & \\
\hline
\end{tabular}

Furthermore, Table 5 gives exorbitant fare as the fourth strongest motivation (35.9\%) for rooftop riding. Going by the income level of the rooftop riders, this finding does not sound far-fetched. The two other real motivations identified by this study for rooftop riding were adventure stunts show-off (34.4\%) and the need for fresh air that the coaches could not guarantee (21.9\%). That there was a need for fresh air in the coaches also suggests that overcrowding was also an issue in the coaches.

As revealed by the submissions of the operations staff, the rooftop was usually a den of all sorts of criminal activities such as stealing, mugging, as well as smoking of Indian hemp and the abuse of and trading in substances and illegal drugs. Some rooftop riders were said to be taking some of the drugs to garner the requisite psychological stamina to ward off any form of fear that was capable of scaring them. Over time, they became addicted to those drugs. Another important finding revealed that irrespective of how random rooftop riding might look, it was characterized by some measure of 'internal' control as ensured by some barons among the riders who had instituted a kind of cartel. No one could just decide to become a rooftop rider overnight, especially on some coaches and at certain stations. Anyone who was not one of them could just not be part of them. However, no one seemed to know what their means of identification was. For these reasons, the operations staff did not subscribe to the notion that poverty was a major driving motivation for rooftop riding. In a way, this viewpoint corroborates the general impression of the lawabiding passengers about the personality of the rooftop riders.

Further analysis reveals that $151(82.5 \%)$ of the lawabiding passengers felt bad and uncomfortable with rooftop riding in Lagos Metropolis and wanted decisive steps taken against the menace. This shows their level of disapproval of the act. All the operations staff shared in the opinion of the majority of the law-abiding passengers as they reported that some of the rooftop riders usually dispossess passengers of their belongings and caused unwarranted mayhems that were not in the interest of the law-abiding passengers, thereby making train ride in the study area unsafe and insecure. However, as many as $24(37.5 \%)$ of the rooftop riders did not favour an end to the practice. Thus, it is deducible that there might be more to the dangerous act than just poverty.

\subsection{Actions against Rooftop Riding}

According to the Head of Operations Department, who confirmed that a lot of lives had been lost consequent upon rooftop riding, efforts taken by the authorities to discourage rooftop riding so far included announcements, public enlightenment and sensitization, pecuniary penalty, as well as regular raids, arrest and prosecution. The issue had been reported to the police several times in the past. At a time, a task force was instituted to complement the efforts of the police. The combined efforts of the task force with the Lagos State police were instituted to checkmate rooftop riding. The police stay at the hot spot stations such as Iddo, Ebute Metta, Agege, Mushin, Ikeja and Oshodi on Mondays, Wednesdays and Fridays, while the task force travels with the train on Mondays, Wednesdays and Fridays. The task force and police arrest rooftop riders and charge them to court. Many of them have been asked to pay heavy fines, and some have even been subjected to community services.

The Head of Operations Department added that in spite of the many arrests that had been made and the prosecutions followed to conclusion, the rooftop riders had remained recalcitrant and even grown hardened and violent. The menace only seems to have reduced drastically in the mornings probably because of the fear of arrest. However, towards the evening time, the miscreants take over and perpetrate the crime with reckless abandon. As such, train rooftop riding has defied all the measures taken against it in the study area.

\section{Conclusions and Recommendations}

From the findings of this study, it is apparent that the despicable activities of rooftop riders constituted a trying experience for the law-abiding passengers and a serious administrative challenge for the operations staff of NRC. The menace was both real and undesirable. It had defied all 
the measures taken against it hitherto in spite of the staggering available records of fatalities. Further evidence from the study reveals that some rooftop riders would want to discontinue rooftop riding; however, some others would rather not consider desisting from the act as they believed it was fun. Meanwhile, that the culprits of this dastardly act were middle-aged and active men could be a major reason behind the failure of all efforts taken to combat it hitherto. In addition, it was found that the majority of law-abiding passengers and operations staff were not at ease with the act and would do anything to see it checkmated. Moreover, to a large extent, investigating rooftop riding is a risky research venture. Evidently, the irresponsible act of train rooftop riding constitutes a major undesirable feature of the Nigerian railway system and should be both condemned and thwarted.

Informed by the findings of this study and adapting some of the suggestions from the respondents, practical policy recommendations that are capable of enhancing the effectiveness of measures against the menace of rooftop riding in the study area are hereby proffered. First, the provision of more trains and the modification of the coaches of existing ones by the management should be conscientiously considered. Second, more widespread and aggressive enlightenment campaigns should be embarked upon for people to better understand the risks involved in train rooftop riding. Third, enhanced spirited enforcement of the no-rooftop-riding rule, especially with the adoption of the brutal but expedient suspension of heavy concrete balls at strategic points over rail tracks, as practised in Indonesia, should be adopted. Finally, precedence should be given to the general improvement in the country's macroeconomic policies with a view to significantly reducing extreme poverty. It is hoped that these would finally put an end to the menace of train rooftop riding and engender a desirable milieu for rail transport in the study area.

Open Access This article is distributed under the terms of the Creative Commons Attribution 4.0 International License (http://crea tivecommons.org/licenses/by/4.0/), which permits unrestricted use, distribution, and reproduction in any medium, provided you give appropriate credit to the original author(s) and the source, provide a link to the Creative Commons license, and indicate if changes were made.

\section{Compliance with Ethical Standards}

Conflict of interest I hereby declare that I have no competing interests in the manuscript.

\section{References}

1. International Railway Safety Council (2018) Railway safety. Retrieved from http://www.international-railway-safety-council. com/safety-statistics/

2. Evans AW (2013) The economics of railway safety. Res Transp Econ 43(1):137-147. https://doi.org/10.1016/j.retrec.2012.12.003

3. Gneiting T (2015) BMXer rides roof of moving train. Retrieved from http://gearchase.com/blog/index.php/bmxer-rides-roof-ofmoving-train/

4. Aridjis H (2014) Migrants ride a 'train of death' to get to America and we're ignoring the root of the problem. Retrieved from https://www.huffingtonpost.com/homero-aridjis/migrants-trainof-death-america-_b_5568288.html

5. Babalola P (2016) NRC working on permanent solution to train rooftop riding in Lagos-District Manager. The Eagle. Retrieved from https://theeagleonline.com.ng/nrc-working-on-permanentsolution-to-train-rooftop-riding-in-lagos-district-manager/

6. Mills K-A (2016) Thrill-seeking headteacher faces sack after caught on camera train surfing with 'his pupils'. Mirror. Retrieved from http://www.mirror.co.uk/news/world-news/thrillseeking-headteacher-faces-sack-8510897

7. McPartland B (2013) Thrill seeker dies 'train surfing' on paris metro. The Local. Retrieved from http://www.thelocal.fr/ 20130524/thrill-seeker-dies-train-surfing-on-paris-metro

8. Sinha A (2016) Police searches for man who decided to stunt it up on Mumbai local. NDTV. Retrieved from http://www.ndtv. com/video/news/news/police-searches-for-man-who-decided-tostunt-it-up-on-mumbai-local-421816

9. Quiano K (2012) Concrete balls thwart roof-riding commuters. CNN Retrieved from http://edition.cnn.com/2012/01/18/world/ asia/indonesia-concrete-balls/index.html

10. The Jakarta Post (2011) Student dead after falling from train rooftop. Retrieved from http://news.asiaone.com/News/Latest\% 2BNews/Asia/Story/A1Story20110510-278039.html

11. The Guardian (2011) 18 Killed riding on top of Indian train. Retrieved from https://www.theguardian.com/world/2011/feb/02/ 18-killed-indian-train

12. The Telegraph (2017) India moves to Ban passengers travelling on top of trains. Retrieved from http://www.telegraph.co.uk/ news/worldnews/asia/india/7260838/India-moves-to-ban-passen gers-travelling-on-top-of-trains.html

13. Chonkar K (2015) Railway authorities to carry out 'Zero Accident Mission' in Mumbai. DNA. Retrieved from http://www. dnaindia.com/locality/mumbai-south-central/railway-authoritiescarry-out-zero-accident-mission-mumbai-68870

14. Aderibigbe A (2016) Rail plots to stop rooftop ride. The Nation. Retrieved from http://thenationonlineng.net/rail-plots-stop-roof top-ride/

15. Glionna JM (2012) Indonesia targets fare-jumpers looking for rooftop train rides. World Now. Retrieved from http://latimes blogs.latimes.com/world_now/2012/02/indonesia-fare-jumper. html

16. Punch (2016) Ride on train roofs, get fined N100,000-NRC. Retrieved from https://punchng.com/ride-train-roofs-get-finedn100000-nrc/

17. Muhammed Y (2016) Mass Transit Trains: NRC arrests 100 rooftop riders. PM News. Retrieved from http://breaking.com.ng/ nigeria/mass-transit-trains-nrc-arrests-100-rooftop-riders/ 
18. Okobi S (2015) Lagos railway police arrest 58 train rooftop riders. This Day. Retrieved from https://allafrica.com/stories/ 201508090101.html

19. Sundiata Post (2015) NRC police arrest 58 train rooftop riders. Retrieved from https://sundiatapost.com/2015/08/06/nrc-policearrest-58-train-rooftop-riders/

20. Tan B (2012) Preventing people from riding on the train rooftop. Retrieved from http://uncle-bugs.blogspot.com/2012/01/prevent ing-people-from-riding-on-train.html

21. The Guardian (2016) Rooftop train riders to pay N100,000 fine soon. Retrieved from https://guardian.ng/news/rooftop-trainriders-to-pay-n100000-fine-soon/

22. Aderibigbe A (2016) Day of rage at Ikeja, Agege train stations. The Nation. Retrieved from http://thenationonlineng.net/dayrage-ikeja-agege-train-stations/

23. Alabi M, Bello KA, Omirin OM (2011) Ratification: mode of securing tenure within Government acquired land in Lagos State, Nigeria. Ife Plan J 4(1):66-84

24. Merem EC, Twumasi YA (2008) Using geospatial information technology in natural resources management: the case of Urban land management in West Africa. Sensors 8(2):607-619. https:// doi.org/10.3390/s8020607

25. World Population Review (2017) Lagos population. Retrieved from http://worldpopulationreview.com/world-cities/lagos-population/
26. Ibidapo-Obe O, Ogunwolu L (2005) An operational appraisal of the Ido-Ijoko Rail Mass Transit System service. Paper presented at the international conference in engineering, Lagos, Nigeria, 23-26 May, pp 30-47

27. Olayiwola KO, Okesoto JO, Akinpelu AA (2012). Assessment of Rail Transport Services on Iddo-Ijoko Corridor. Paper presented at the first National Conference on Technological Advancement and the Built Environment, School of Environmental Studies, Yaba College of Technology, Yaba, Lagos, Nigeria. 13-14 June, pp 1-12

28. Premium Times (2014) Nigerian Government Inaugurates New Train Coaches in Lagos. Retrieved from https://www.pre miumtimesng.com/news/162460-nigerian-government-inaugu rates-new-trains-coaches-in-lagos.html

29. University of Portsmouth (2012) Advantages and disadvantages of conducting observational research. Retrieved from http://com pass.port.ac.uk/UoP/file/664e8001-f121-4e5d-aa066c95c797e8af/1/Observations_IMSLRN.zip/page_04.htm

30. Weller C (2017) The World Bank released new poverty linesfind out where your country stands. Business Insider, South Africa. Retrieved from https://www.businessinsider.com/worldbank-released-new-poverty-lines-see-where-your-country-falls2017-10?IR=T 